\title{
Transitional-Cell Carcinoma of the Endometrium: A Rare Case Report
}

\author{
Preeti Rajendra Sahu¹, Kishor Madhukar Hiwale², Sunita Jayant Vagha³ \\ ${ }^{1}$ Department of Pathology, Jawaharlal Nehru Medical College, Acharya Vinoba Bhave Rural Hospital, Sawangi (Meghe) \\ Wardha, Maharashtra, India. ${ }^{2}$ Department of Pathology, Jawaharlal Nehru Medical College, Acharya Vinoba Bhave \\ Rural Hospital, Sawangi (Meghe) Wardha, Maharashtra, India. ${ }^{3}$ Department of Pathology, Jawaharlal Nehru Medical \\ College, Acharya Vinoba Bhave Rural Hospital, Sawangi (Meghe) Wardha, Maharashtra, India.
}

\section{INTRODUCTION}

Transitional cell carcinoma is a very rare histological subtype of endometrial cancer. To date, only 21 cases of transitional cell carcinoma of the endometrium have been reported in the international literature. Due to the rarity of this disease, current management is controversial and includes various approaches, mostly described in the adjuvant setting, both radiotherapy and chemotherapy alone or in combination. Here, we report a case of a 62-year-old patient who underwent radical total abdominal hysterectomy and bilateral salpingo-oophorectomy (TAH-BSO)

Transitional Cell Carcinomas (TCC) of endometrium are unusual tumours occurring in the female genital tract, most commonly occurring in the ovary, accounting to nearly $2 \%$ of the carcinomas. ${ }^{2}$ Rarest site of presentation of TCC is Endometrium and with least number of cases having diagnosed primitive endometrial disease which are described in literature. $3,4,5,6,7,8,9,10,11$ Therefore, it is very troublesome for these patients to have any definite guidance with regard to after-surgery adjuvant therapy, due to different adjunct treatments, including external beam radiotherapy, brachytherapy or the internal radiation therapy and chemo which were previously used.

Therefore, we report an unexpected face-off / confrontation with a highly unusual case of pure endometrial TCC, where we treated the patient with surgery as the patient declined any kind / modality of further treatment.

\section{PRESENTATION OF CASE}

A 62-year-old woman presented in the gynaecology department with chief complaints of post-menopausal bleeding, occurring since 7 months. General and clinical examination were done. USG showed endometrial mass and endometrial thickness $24 \mathrm{~mm}$ with high vascularity on Doppler and presence of fluid collection adjacent to endometrium. She was sickle cell trait and HBsAg positive.

Hysteroscopy and biopsy could not be performed due to patient's denial for prior minor procedure. Radical total abdominal hysterectomy and bilateral salpingooophorectomy (TAH-BSO) was carried out minus the sampling of lymph nodes. On frozen section, diagnosis given was primary carcinoma endometrium of high grade. Post-operative period was uneventful. Uterus with cervix and bilateral adnexa was submitted for histopathological examination. With the agreement of interdisciplinary team, it was decided to conserve the patient under surveillance and adjunct therapy was not required post-surgery.

Macroscopically, uterus measured $6 \times 6 \times 3 \mathrm{cms}$, and the cervix was $3 \mathrm{cms}$ long. Cauliflower like friable growth was seen which was obliterating the entire endometrial cavity involving bilateral cornua and up to the internal os, infiltrating into the myometrium. No gross abnormality was seen in either fallopian tubes or the ovaries.

\author{
Corresponding Author: \\ Dr. Preeti Sahu. \\ Department of Pathology, \\ Jawaharlal Nehru Medical College, \\ Acharya Vinoba Bhave Rural Hospital, \\ Sawangi (Meghe) Wardha, \\ Maharashtra, India. \\ E-mail: preetisahu9811@gmail.com
}

DOI: $10.14260 / j e m d s / 2020 / 579$

How to Cite This Article:

Sahu PR, Hiwale KM, Vagha SJ.

Transitional-cell carcinoma of the endometrium: a rare case report. I Evolution Med Dent Sci 2020;9(36):26662668, DOI: $10.14260 /$ jemds/2020/579

Submission 19-05-2020,

Peer Review 28-07-2020,

Acceptance 03-08-2020,

Published 07-09-2020.

Copyright (C) 2020 JEMDS. This is an open access article distributed under Creative Commons Attribution License [Attribution 4.0 International (CC BY 4.0)] 
Histological examination showed cells which were tightly packed and arranged in papillary like growth of urothelial like multi-layered transitional epithelium with high grade anaplasia with central fibrovascular stalks, stromal invasion, lympho-vascular invasion, area of haemorrhage and areas of necrosis invading the underlying myometrium.

In histopathological report, it was established that endometrial lesion was an uncommon case of pure variant of transitional cell carcinoma having a TNM Staging-T1b Nx Mx.
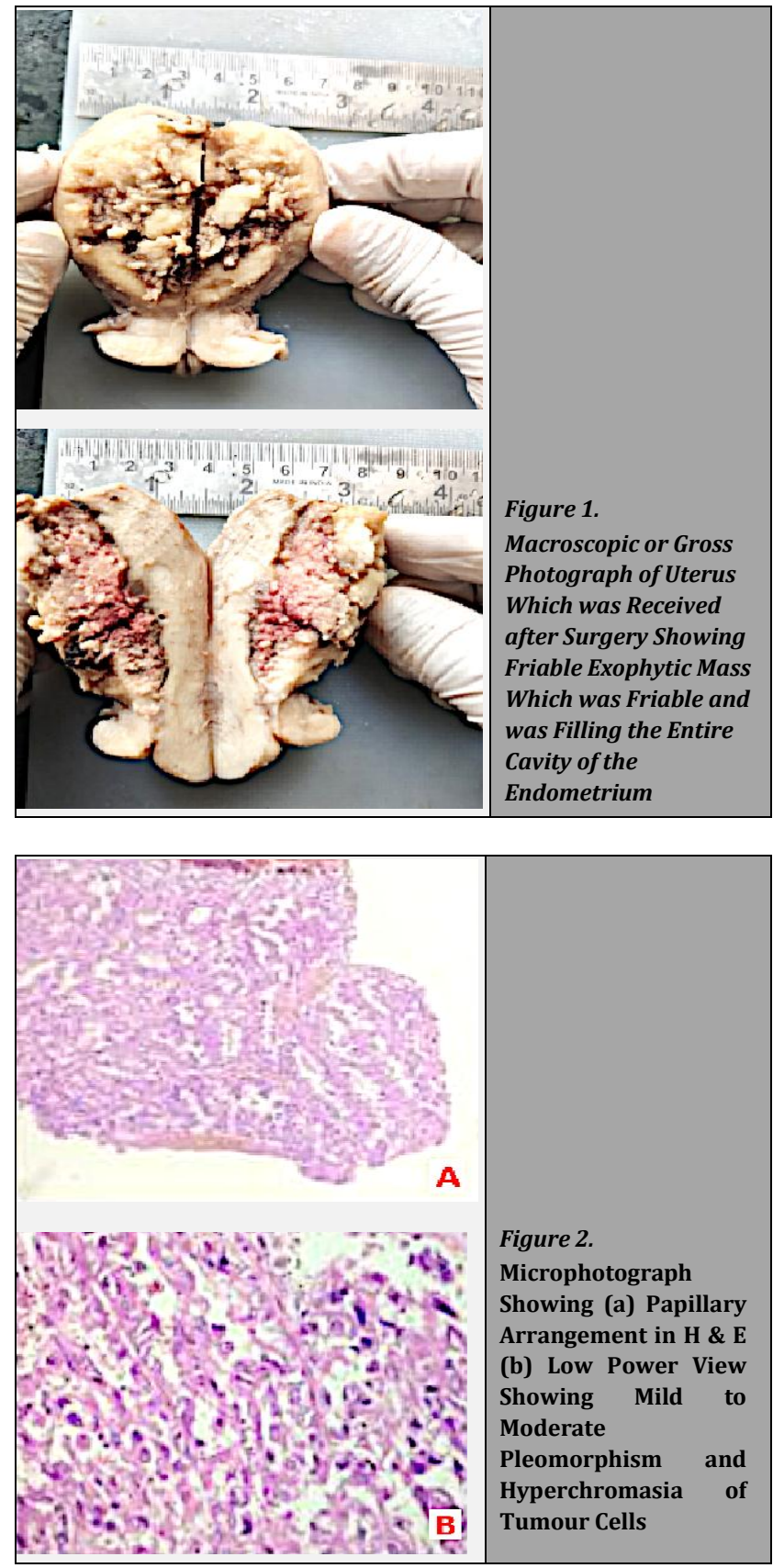

\section{DISCUSSION}

Here we report our encounter with the pure variant of TCC of endometrium where TAH-BSO was performed as a treatment modality. TCC are infrequent occurring neoplasms in female reproductive tract. Ovarian transitional cell carcinoma is an infamous entity ${ }^{12,13}$ but these tumours had also been seen in the cervix, fallopian tubes and endometrium ${ }^{3-7,13,14}$
Chiefly postmenopausal women happened to have TCC of the endometrium and in the maximum number of times complained of postmenopausal bleeding. ${ }^{9}$

Our patient also presented as postmenopausal bleeding were pelvic examination with ultrasound, revealed an enlarged uterine body with an irregular endometrial surface in the case. Patient was sickle cell trait with HBsAg positive. These finding could have been just by chance events, but also could have involve a response to a neoplastic process.

These tumours have not been correlated with endometrial hyperplasia.

Primary TCC are markedly uncommon, which are only confined as case-report with published references. Because of its uncommonness, minimum knowledge is accessible concerning its relative occurrence, its behaviour and modality of treatment and its result. A review of literature of primary endometrial TCC and endometrial carcinoma with differentiation of transitional cell type revealed only 21 cases. ${ }^{1}$ There are multiple aspects in regard to endometrial TCCs which remains a controversial carcinoma because of its histogenesis and Human Papilloma Virus role as the causative agent.

According to Lininger et al the tumour is said to be Transitional cell carcinoma of endometrium when the tumour component of TCC is more than $50 \%$. Lesion with $<50 \%$ of TCC will be called as endometrial carcinoma with differentiation of transitional cell carcinoma. ${ }^{5}$

We need to be careful not to make the diagnosis of endometroid tumours having squamous cell differentiation and coarse papillary structures pattern which are lined by thickened epithelium as TCC of the endometrium. ${ }^{9}$

Tumours occurring in the uterine corpus mandates more than $90 \%$ tumour cells to be analogous of transition cell so as to be called as pure Transitional cell ca of the endometrium as stated by WHO classification. ${ }^{15}$

Considering this definition, only 11 cases in the literature can be considered as pure endometrial TCC, while the others as endometrial ca having transitional cell differentiation. The majority of TCC cases reported have components of other carcinomas, mainly endometroid components. ${ }^{1}$

The histogenesis of endometrial TCC is idiopathic. ${ }^{16}$

The diagnosis of the presence of transition cell differentiation in endometrial ca is based on haematoxylin and eosin finding as well as immunohistochemical analysis. ${ }^{1}$

Lininger et al in their study found that in papillary TCCs of the bladder both CK 7 and CK 20 were reactive showing positivity while in contrary majority of the cases of endometrial TCCs were found to have CK 7 positive and CK 20 negative. ${ }^{5}$

It has also been proposed that TCC differentiation is a neoplastic metamorphosis of endometroid carcinomas. ${ }^{5,11,17}$

\section{CONCLUSIONS}

TCC is an atypical form of endometrial carcinoma having characteristic histological and immunophenotypic features. Identification of this abnormal form of endometrial carcinoma expands the morphological spectra of epithelial neoplasm of endometrium. Further studies should clarify if this unusual growth pattern is relevant for clinical outcome. Therefore, notation of any amount of the presence of TCC differentiation 
in endometrial carcinoma is necessary, so that more can be learned about the potential clinical and prognostic impact of this unusual histologic pattern. ${ }^{16}$

Financial or Other Competing Interests: None.

\section{REFERENCES}

[1] Cubo-Abert M, Rodríguez-Mías NL, Capote S, et al. Advanced stage of primary transitional-cell carcinoma of the endometrium: a case report and literature review. Journal of Gynecologic Surgery 2018;34(2).

[2] De Cecio R, Cantile M, Collina F, et al. Borderline Brenner tumor of the ovary: a case report with immunohistochemical and molecular study. J Ovarian Res 2014;7:101.

[3] Chen KT. Extraovarian transitional cell carcinoma of female genital tract. Am J Clin Pathol 1990;94(5):670-1.

[4] Spiegel GW, Austin RM, Gelven PL. Transitional cell carcinoma of the endometrium. Gynecol Oncol 1996;60(2):325-30.

[5] Lininger RA, Ashfaq R, Albores-Saavedra J, et al. Transitional cell carcinoma of the endometrium and endometrial carcinoma with transitional cell differentiation. Cancer 1997;79(10):1933-43.

[6] Fukunaga M, Ushigome S. Transitional cell carcinoma of the endometrium. Histopathology 1998;32(3):284-86.

[7] Labonté S, Têtu B, Boucher D, et al. Transitional cell carcinoma of the endometrium associated with a benign ovarian Brenner tumor: a case report. Hum Pathol 2001;32(2):230-2.

[8] Mariño-Enríquez A, González-Rocha T, Burgos E, et al. Transitional cell carcinoma of the endometrium and endometrial carcinoma with transitional cell differentiation: a clinic pathologic study of 5 cases and review of the literature. Hum Pathol 2008;39(11):160613.
[9] Ahluwalia M, Light AM, Surampudi K, et al. Transitional cell carcinoma of the endometrium: a case report and review of the literature. Int J Gynecol Pathol 2006;25(4):378-82.

[10] Ribeiro-Silva A. Immunohistochemical features of a papillary squamous cell carcinoma of the endometrium with transitional cell differentiation. Diagn Pathol 2007;2:26.

[11] Lum D. Primary transitional cell carcinoma of the endometrium. Pathology 2005;37(6):554-7.

[12] Eichhorn JH, Young RH. Transitional cell carcinoma of the ovary: a morphologic study of 100 cases with emphasis on differential diagnosis. Am J Surg Pathol 2004;28(4):453-63.

[13] Koenig C, Turnicky RP, Kankam C, et al. Papillary squamotransitional cell carcinoma of the cervix: a report of 32 cases. Am J Surg Pathol 1997;21(8):915-21.

[14] Uehira K, Hashimoto H, Tsuneyoshi M, et al. Transitional cell carcinoma pattern in primary carcinoma of the fallopian tube. Cancer 1993;72(8):2447-56.

[15] Tavassoli FA, Devilee P, eds. Epithelial tumors and related lesions. In: World Health Organization Classification of tumors: pathology and genetics of tumors of the breast and female genital organs. Lyon, France: International Agency for Research on Cancer (IARC) Press 2003: p. 221.

[16] Mariño-Enríquez A, González-Rocha T, Burgos E, et al. Transitional cell carcinoma of the endometrium and endometrial carcinoma with transitional cell differentiation: a clinicopathologic study of 5 cases and review of the literature. Hum Pathol 2008;39(11):160613.

[17] Giordano G, D'Adda T, Gnetti L, et al. Transitional cell carcinoma of the endometrium associated with benign ovarian brenner tumor: a case report with immunohistochemistry molecular analysis and a review of the literature. Int J Gynecol Pathol 2007;26(3):298304. 